\title{
PERILAKU PENGGUNAAN KONTRASEPSI PADA PUS SELAMA PANDEMI COVID-19 DI WILAYAH KERJA PUSKESMAS KUTA UTARA
}

\author{
${ }^{1)}$ Ni Made Rai Widiastuti, ${ }^{2)}$ Ketut Novia Arini \\ Diploma III Kebidanan, Politeknik Kesehatan Kartini Bali \\ Jl Piranha No 2 Pegok Sesetan Denpasar Bali \\ ${ }^{1)}$ raiwidiastuti@gmail.com ${ }^{2)}$ ktnovia85@gmail.com
}

\section{Kata Kunci:}

Perilaku; Kontrasepsi;

Pandemi, COVID-19

Keywords:Behavior; Contraception,COVID19;Pandemic

\section{Info Artikel}

Tanggal dikirim: 19-03-2021

Tanggal direvisi: 05-04-2021

Tanggal diterima: 21-07-2021

DOI Artikel:

10.36341/jomis.v5i2.1741

Creative Commons Attribution-

NonCommercial-ShareAlike 4.0 International License.

\begin{abstract}
ABSTRAK
Pemerintah Indonesia telah menetapkan penyebaran virus COVID-19 sebagai Bencana Nasional, dan untuk pencegahan penularannya dilakukan dengan menerapkan kebijakan Pembatasan Sosial Berskala Besar (PSBB). Kebijakan ini secara tidak langsung berdampak pada semua aspek kehidupan salah satunya adalah dalam pelayanan KB. Secara Nasional hasil pelayanan KB pada masa pandemi COVID-19 terdapat penurunan jumlah penggunaan alat kontrasepsi yang mencapai $40 \%$ dan terjadi diseluruh wilayah di Indonesia (BKKBN, 2020). Hal ini dapat menimbulkan berbagai masalah diantaranya terjadi peningkatan angka kehamilan yang tidak diinginkan (unwanted pregnancy) dan baby boom atau peningkatan angka kelahiran. Hasil penelitian ini bertujuan untuk mengetahui bagaimana perilaku penggunaan kontrasepsi pada pasangan usia subur dalam masa pandemi COVID-19 di Puskesmas Kuta Utara. Penelitian ini adalah jenis penelitian survey dengan rancangan penelitian cross sectional analitik. Populsai dalam penelitian ini adalah seluruh Pasangan Usia Subur (PUS) dengan jumlah sampel adalah 365 responden yang diambil secara purposive sampling. Hasil penelitian ini didapatkan bahwa sebagian responden saat ini menggunakan kontrasepsi. Analisis data bivariat dengan chi square didapatkan variabel umur, paritas, penghasilan keluarga, persepsi manfaat, persepsi hambatan, ketersediaan tempat pelayanan, dan dukungan suami berhubungan dengan perilaku penggunaan kontrasepsi. Analisis multivariat dengan teknik regresi logistik didapatkan bahwa variabel dukungan suami yang paling dominan berpengaruh terhadap perilaku penggunaan kontrasepsi.
\end{abstract}

\section{ABSTRACT}

The Indonesian government has designated the spread of the COVID-19 virus as a National Disaster, and to prevent its transmission it is carried out by implementing the Large Scale Social Restriction (PSBB) policy. This policy indirectly affects all aspects of life, one if which is in family planning services. Nationally, the results of family planning services during the COVID-19 pandemic, there was a decrease in the use of contraceptives reaching. This can cause various problems including an increase in the number of unwanted pregnancies (unwanted pregnancy) and baby booms or an increase in the birth rate. This study aims to determine how the behavior of contraceptive use among couples of childbearing age during the COVID-19 pandemic at the Primary Health Care North Kuta. This research is a survey research with cross sectional analytic research design. The population in this study were all fertile age couples (PUS) in Denpasar City and the number of samples used was 365 respondents with a purposive sampling technique. The results of this study found that most respondents are currently using contraception. Analysis of bivariate data with chi square obtained variables of age, parity, family income, perceived benefits, perceived barriers, availability of service places, and husband's support, affect the behavior of contraceptive use. Multivariate analysis with logistic regression found that husband's support variable has the most dominant influence on contraceptive use behavior. 


\section{PENDAHULUAN}

Indonesia adalah negara berkembang dengan jumlah penduduk yang menempati posisi ke empat dengan laju pertumbuhan penduduk dan jumlah penduduk yang tinggi didunia setelah negara Cina, India dan Amerika Serikat. Berbagai cara dilakukan sebagai upaya dalam pengendalian jumlah penduduk dengan menerapkan program Keluarga Berencana (KB). Salah satu target indikator keberhasilan Sustainability Development Goals (SDG's) pada Tahun 2030, yaitu menjamin akses secara menyeluruh (universal access) untuk pelayanan kesehatan seksual, kesehatan reproduksi dan keluarga berencana [1].

Mengingat angka kelahiran yang tinggi, akan berdampak pada kesehatan ibu dengan indikator AKI, sehingga angka kematian ibu bisa tidak terjadi jika seorang wanita tidak dalan keadaan hamil. Maka dari itu kondisi kehamilan, terlebih lagi kehamilan yang berisiko tinggi dapat sebagai jalan menuju kematian ibu, jika kehamilan tersebut tidak mendapatkan penatalaksanaan dengan baik [1].

Program keluarga berencana untuk mengatur jarak kelahiran, usia ideal melahirkan, mengatur waktu kehamilan dengan upaya promosi guna mewujudkan keluarga yang idel dan berkualitas. Program KB di Indonesia sudah dicanangkan sejak tahun 1970, telah mengalami berbagai perubahan dan perkembangan. Salah satu indikator keberhasilan dari program keluarga berencana diIndonesia adalah ditunjukkan dengan meningkatnya angka kesertaan berKB atau
Contraceptive Prevalence Rate (CPR), yang dapat dilihat dari angka kesertaan ber KB dengan cara modern yaitu kontrasepsi implant, metode operasi wanita,metode operasi pria, Alat Kontrasepsi Dalam Rahim (AKDR), suntikan, pil dan kondom[1].

Saat ini dunia sedang mengalami pandemi Virus Corona (Covid-19) yang menjadi masalah kesehatan dunia dan telah menginfeksi secara global termasuk Indonesia[2]. Pandemi Covid-19 belum bisa dipastikan kapan akan berakhir, sehingga kondisi ini membuat seluruh lapisan masyarakat perlu beradaptasi dan menerapkan protokol kesehatan baru agar tetap dapat beraktivitas namun tetap aman dari penularan Covid-19[3].

Keputusan Presiden Nomor 12 tahun 2020 tentang Penetapan Bencana non alam penyebaran COVID-19 sebagai Bencana Nasional, memerlukan mekanisme penanganan salah satunya dengan diberlakukan kebijakan Pembatasan Sosial Berskala Besar (PSBB)[4]. Kebijakan Pembatasan Sosial Berskala Besar (PSBB) untuk pencegahan penularan COVID-19, menyebabkan dampak yang sangat besar disemua aspek kehidupan salah satunya adalah dalam hal pelayanan KB. Adanya PSBB tersebut dapat menyebabkan perubahan perilaku pasangan usia subur, seperti akan mengurangi jumlah kunjungan ke fasilitas kesehatan, seluruh aktifitas dilakukan dirumah baik aktifitas pekerjaan, belajar, dan lain-lain, yang semua ini akan berdampak pada perilaku pasangan usia subur tersebut.

Hambatan lainnya yang terjadi dalam pelayanan keluarga berencana 
yaitu terjadi keterbatasan mengakses pelayanan dan kekurangan alat kontrasepsi akibat dari suplai alat yang terganggu, terlebih lagi terjadi pada negara berkembang[5]. Hal yang sama telah disampaikan bahwa pandemi Covid-19 merubah pola hidup seluruh masyarakat dan memberikan dampak terhadap pola penggunaan alat kontrasepsi serta mempengaruhi distribusi obat dan alat kontrasepsi[6]. UNFPA menyampaikan bahwa selama pandemic Covid-19 harus tetap tersedia alat kontrasepsi modern jangka panjang (MKJP) dan metode kontrasepsi jangka pendek (non MKJP), layanan informasi, koseling, termasuk kontrasepsi darurat harus selalu tersedia serta dapat diakses oleh masyarakat[7].

Secara Nasional hasil pelayanan KB pada masa pandemi COVID-19 terdapat penurunan jumlah penggunaan alat kontrasepsi yang mencapai $40 \%$ dan hampir terjadi diseluruh wilayah di Indonesia[3]. Badan Kependudukan dan Keluarga Berencana Nasional (BKKBN) memprediksi baby boom atau ledakan angka kelahiran berpotensi terjadi selama masa pandemi dan meningkatnya drop out atau putus kesertaan ber-KB. Hal ini disebabkan dari terhambatnya akses untuk mendapatkan pelayanan, menunda ke fasilitas kesehatan oleh karena kekhawatiran tertular COVID19 dan peningkatan hubungan suami istri tanpa menggunakan alat kontrasepsi yang memiliki resiko hamil[3].

Berdasarkan latar belakang diatas peneliti ingin mengetahui bagaimana perilaku PUS dalam menggunakan kontrasepsi selama pandemi COVID-19 di Kecamatan
Kuta Utara Kabupaten Badung. Perilaku PUS dalam menggunakan kontrasepsi dalam hal ini dilihat berdasarkan tiga faktor yang mempengaruhi yaitu faktor predisposisi (predisposing factors), faktor pemungkin (enabling factors) dan faktor penguat (reinforcing faktors).

\section{TINJAUAN PUSTAKA}

Coronavirus adalah keluarga besar virus yang menyebabkan penyakit mulai dari gejala ringan sampai berat. Terdapat dua jenis virus corona yang dapat menimbulkan gejala berat seperti Middle East Respiratory Syndrome (MERS) dan Severe Acute Respiratory Syndrome (SARS). Virus penyebab COVID-19 ini dinamakan Sars-CoV-2 adalah penyakit jenis virus baru yang belum pernah diidentifikasi sebelumnya pada manusia.. [8]. Tanda dan gejala umum seseorang terinfeksi COVID-19 antara lain gangguan pernapasan yang akut seperti demam, flu, batuk dan sesak napas. Masa inkubasi virus adalah rata-rata 5-6 hari dengan masa inkubasi terpanjang adalah 14 hari. Pada kasus COVID-19 yang berat dapat menyebabkan terjadinya pneumonia, sindrom pernapasan akut, gagal ginjal, dan kematian. Tanda dan gejala klinis yang paling banyak dilaporkan adalah demam, sesak napas serta hasil rontgen dada mengambarkan terjadinya infiltrat pneumonia yang luas pada kedua paru [9].

Selama pelaksanaan tanggap darurat COVID-19, agar tidak terjadi DO pelayanan $\mathrm{KB}$ tetap berlajan dengan memperhatikan protokol-protokol penyebaran virus corona. BKKBN telah gencar melakukan sosialisasi untuk menggunakan menggunakan kontrasepsi alternatif yaitu pil $\mathrm{KB}$, kondom dan alat kontrasepsi lainnya selama mengikuti program pemerintah yaitu di rumah saja. 
Penggunaan alat kontrasepsi berupa pil KB tersebut menjadi salah satu alternatif bagi peserta $\mathrm{KB}$ aktif yang selama ini menggunakan metode suntik. Dalam situasi saat ini, pelayanan suntik KB di fasilitas kesehatan dibatasi, sebagai upaya menghindari kontak langsung antara petugas dan masyarakat. BKKBN tetap menjalankan penyuluhan yang disesuaikan dengan melakukan sosialisasi program KB secara daring atau online dengan memanfaatkan media sosial yang dilakukan oleh para kader KB di wilayah kerja masing-masing[3].

Pada kondisi sekarang ini diharapkan PUS dengan resiko $4 \mathrm{~T}$ tidak hamil terlebih dahulu, sehingga petugas kesehatan perlu memastikan bahwa mereka saat ini sedang menggunakan alat kontrasepsi [2]. Beberapa hasil penelitian yang menunjukkan bahwa wabah infeksi dapat mempengaruhi program penggunaan kontrasepsi yaitu penurunan distribusi kontrasepsi sebesar $65 \%$ di negara Liberia dan 23\% di Sierra Leone pada puncak wabah Ebola Afrika Barat. Secara global pencegahan kasus COVID19 yang terjadi diseluruh dunia saat ini terfokus pada upaya perawatan medis, pembagian sumber daya, pencegahan penyebaran virus, pengembangan obat dan vaksin terbaru. Disisi lain konsekuensi dari terhambatnya akses terhadap pelayanan kontrasepsi, sesuai dengan hasil penelitian yang dilakukan oleh badan kesehatan seksual dan reproduksi Perserikatan Bangsa-Bangsa (UNFA) didapatkan bahwa lebih dari 47 juta wanita kehilangan akses kontrasepsi yang menyebabkan 7 juta kehamilan yang tidak diinginkan sebagai akibat krisis COVID19. Akses terhadap pelayanan kontrasepsi merupakan akses vital karena selama 20 tahun terakhir, peningkatan penggunaan kontrasepsi dinegara berkembang telah dapat mengurangi jumlah kematian ibu sebesar $40 \%$ dari penurunan kehamilan yang tidak diinginkan[5]. Oleh karena itu diharapkan program keluarga berencana dapat terus dilakukan ditengah masyarakat.

Keberhasilan program KB ditentukan dari perilaku PUS untuk ikut berpartisipasi sebagai akseptor KB. Perilaku dalam hal ini yang dimaksud adalah perilaku kesehatan seseorang yang dapat dilihat dari aktivitas atau kegiatan seseorang baik yang dapat diamati (observable) maupun yang tidak dapat diamati (unobservable) yang berkaitan dengan pemeliharaan dan peningkatan kesehatan seseorang. Perilaku dalam pemakaian kontrasepsi, sebagaimana diketahui bahwa perilaku seseorang dipengaruhi oleh 3 faktor utama menurut Laurence W.Green (1980) dalam Notoadmodjo (2012) yaitu: 1) Faktor predisposisi (predisposing factors), yang mencakup faktor umur, pendidikan, pekerjaan, penghasilan, pengetahuan dan sikap. 2) Faktor pemungkin (enabling factors) yang mencakup fasilitas penunjang, sumber informasi dan kemampuan sumber daya. 3) Faktor penguat (reinforcing faktors) yang mencakup dukungan keluarga, kelompok, petugas kesehatan dan tokoh masyarakat yang mendukung perilaku [10].

Selain itu persepsi juga sangat mempengaruhi perilaku seseorang untuk melakukan suatu tindakan yang ditegaskan dalam Teori Health belife model (HBM). Model teori ini digunakan untuk mengeksplorasi prilaku kesehatan seseorang dalam jangka panjang dan jangka pendek. Model teori ini akan mencakup beberapa unsur penting, yang dapat memungkinkan seseorang melakukan tindakan pencegahan yang dipengaruhi oleh beberapa hal, yaitu perceived susceptibility, perceived severity, perceived benefits dan perceived barrier[11].

\section{METODE}

Metode yang digunakan adalah analitik dan rancangan crosssectional. Penelitian dilakukan dari bulan April-Juli 2020, menggunakan sampel 365 ibu hamil yang sesuai dengan kriteria inklusi yaitu wanita usia subur yang berada pada 
wilayah kerja Puskesmas Kuta Utara, tidak sedang dalam keadaan hamil dan tidak sedang program kehamilan. Pada penelitian ini menggunakan teknik Purposive Sampling.

Penelitian ini menggunakan kuesioner elektronik dengan google formulir sebagai alat pengumpulan data. Analisis data bivariate menggunakan uji Korelasi Chi Square dan analisis multivariat menggunakan regresi logistic ganda. No etik penelitian : 1799/UN14.2.2.VII.14/LT/2020

HASIL DAN PEMBAHASAN

Tabel 1. Distribusi Frekuensi Karakteristik Responden

\begin{tabular}{lll}
\hline $\begin{array}{l}\text { Karakteristik } \\
\text { Responden }\end{array}$ & $\begin{array}{l}\text { Frekuensi } \\
(\mathbf{n})\end{array}$ & $\begin{array}{l}\text { Persentase } \\
(\%)\end{array}$ \\
\hline $\begin{array}{l}\text { Umur } \\
<20 \text { tahun }\end{array}$ & 2 & 0,5 \\
$\begin{array}{l}\text { 20-35 tahun } \\
>35 \text { tahun }\end{array}$ & 191 & 52,3 \\
$\begin{array}{l}\text { Tingkat } \\
\text { Pendidikan }\end{array}$ & 172 & 47,2 \\
$\begin{array}{l}\text { Pendidikan } \\
\text { Dasar }\end{array}$ & 35 & \\
$\begin{array}{l}\text { Pendidikan } \\
\text { Menengah }\end{array}$ & 136 & 9,6 \\
$\begin{array}{l}\text { Pendidikan } \\
\text { Tinggi }\end{array}$ & 194 & 37,3 \\
$\begin{array}{l}\text { Pekerjaan } \\
\text { Bekerja }\end{array}$ & 268 & 53,2 \\
$\begin{array}{l}\text { Tidak bekerja } \\
\text { Paritas }\end{array}$ & 97 & \\
1-2 & & 26,4 \\
$>2$ & 285 & 78,1 \\
$\begin{array}{l}\text { Penghasilan } \\
\text { Keluarga }\end{array}$ & 80 & 21,9 \\
$\begin{array}{l}\text { Rendah } \\
\text { Tinggi }\end{array}$ & 139 & 38,1 \\
\hline
\end{tabular}

Dari tabel 1 pada data karakteristik responden didapatkan bahwa sebagian besar yaitu $52,5 \%$ responden berumur 2035 tahun, sebagian besar yaitu 53,2\% dengan pendidikan tinggi, sebagian besar yaitu 73,4 \% responden adalah bekerja, sebagian besar yaitu $78,1 \%$ dengan paritas
1-2 anak, dan sebagian besar yaitu $61,9 \%$ dengan penghasilan keluarga yang tinggi (lebih dari atau sama dengan UMK Kabupaten Badung).

Tabel 2. Distribusi Frekuensi Perilaku Penggunaan KB Pada Masa Pandemi COVID-19

\begin{tabular}{lcc}
\hline $\begin{array}{l}\text { Perilaku } \\
\text { Penggunaan } \\
\text { KB }\end{array}$ & $\begin{array}{c}\text { Frekuen } \\
\text { Si } \\
\text { (n) }\end{array}$ & $\begin{array}{c}\text { Presentas } \\
\text { e }(\%)\end{array}$ \\
\hline $\begin{array}{l}\text { Tidak } \\
\text { Menggunaka }\end{array}$ & 171 & 46,8 \\
$\mathrm{n}$ & & \\
$\begin{array}{l}\text { Menggunaka } \\
\mathrm{n}\end{array}$ & 194 & 53,2 \\
Total & 365 & 100
\end{tabular}

Berdasarkan tabel 2 diatas didapatkan bahwa setengahnya yaitu $53,2 \%$ responden sedang menggunakan alat kontrasepsi dan hampir setengahnya yaitu $46,8 \%$ responden tidak menggunakan alat kontrasepsi. 
Tabel 3. Analisis Bivariat Hubungan Variabel Independen dengan Perilaku Pemakaian Kontrasepsi Selama Pandemi COVID-19

\begin{tabular}{|c|c|c|c|c|c|c|}
\hline \multirow{3}{*}{ No } & \multirow{3}{*}{$\begin{array}{r}\text { Variabel } \\
\text { Independen }\end{array}$} & \multicolumn{2}{|c|}{ Perilaku Penggunaan } & \multirow{3}{*}{$\begin{array}{c}\text { Crude } \\
\text { OR }\end{array}$} & \multirow{3}{*}{$95 \% \mathrm{CI}$} & \multirow{3}{*}{ Nilai $p$} \\
\hline & & Tidak & Ya & & & \\
\hline & & n (\%) & n (\%) & & & \\
\hline 1 & $\begin{array}{l}\text { Umur } \\
\leq 35 \text { tahun } \\
>35 \text { tahun }\end{array}$ & $\begin{array}{c}105(54,4) \\
66(38,4)\end{array}$ & $\begin{array}{c}88(45,6) \\
106(61,6)\end{array}$ & 9,38 & $1,26-2,91$ & 0,00 \\
\hline 2 & $\begin{array}{l}\text { Pendidikan } \\
\text { Rendah } \\
\text { Tinggi }\end{array}$ & $\begin{array}{c}19(53,3) \\
152(46,1)\end{array}$ & $\begin{array}{c}16(45,7) \\
178(53,9)\end{array}$ & 1,39 & $0,69-2,80$ & 0,35 \\
\hline 3 & $\begin{array}{l}\text { Pekerjaan } \\
\text { Bekerja } \\
\text { Tidak Bekerja }\end{array}$ & $\begin{array}{c}124(46,3 \%) \\
47(48,5 \%)\end{array}$ & $\begin{array}{c}144(53,7 \%) \\
50(51,5 \%)\end{array}$ & 0,92 & $0,57-1,45$ & 0,71 \\
\hline 4 & $\begin{array}{l}\text { Paritas } \\
1-2 \\
>2 \\
\end{array}$ & $\begin{array}{c}142(49,8 \%) \\
29(36,2 \%)\end{array}$ & $\begin{array}{c}143(50,2 \%) \\
51(63,7 \%)\end{array}$ & 1,75 & $1,05-2,91$ & 0,03 \\
\hline 5 & $\begin{array}{l}\text { Penghasilan } \\
\text { Keluarga } \\
\text { Rendah } \\
\text { Tinggi }\end{array}$ & $\begin{array}{l}51(36,7 \%) \\
120(53,1 \%)\end{array}$ & $\begin{array}{c}88(63,3 \%) \\
106(46,9 \%)\end{array}$ & 0,5 & $0,33-0,79$ & 0,00 \\
\hline 6 & $\begin{array}{l}\text { Pengetahuan } \\
\text { Rendah } \\
\text { Tinggi }\end{array}$ & $\begin{array}{c}31(43,3 \%) \\
140(47,8 \%)\end{array}$ & $\begin{array}{c}41(56,9 \%) \\
153(52,2 \%)\end{array}$ & 0,8 & $0,49-1,38$ & 0,47 \\
\hline 7 & $\begin{array}{l}\text { Persepsi } \\
\text { Rerentanan } \\
\text { Rendah } \\
\text { Tinggi }\end{array}$ & $\begin{array}{c}42(50,6 \%) \\
129(45,7 \%)\end{array}$ & $\begin{array}{c}41(49,4 \%) \\
153(54,3 \%)\end{array}$ & 1,2 & $0,74-1,98$ & 0,44 \\
\hline 8 & $\begin{array}{l}\text { Persepsi } \\
\text { Keseriusan } \\
\text { Rendah } \\
\text { Tinggi }\end{array}$ & $\begin{array}{c}55(53,4 \%) \\
116(44,3 \%)\end{array}$ & $\begin{array}{c}48(46,6 \%) \\
146(55,7 \%)\end{array}$ & 1,4 & $0,91-2,28$ & 0,12 \\
\hline 9 & $\begin{array}{l}\text { Persepsi } \\
\text { Manfaat } \\
\text { Rendah } \\
\text { Tinggi }\end{array}$ & $\begin{array}{c}36(85,7 \%) \\
135(41,8 \%)\end{array}$ & $\begin{array}{c}6(14,3 \%) \\
188(58,2 \%)\end{array}$ & 8,36 & $3,42-20,39$ & 0,00 \\
\hline 10 & $\begin{array}{l}\text { Persepsi } \\
\text { Hambatan } \\
\text { Rendah } \\
\text { Tinggi }\end{array}$ & $\begin{array}{c}84(36,7 \%) \\
87(64 \%)\end{array}$ & $\begin{array}{c}145(63,3 \%) \\
49(36 \%)\end{array}$ & 0,33 & $0,21-0,51$ & 0,00 \\
\hline 11 & $\begin{array}{l}\text { Ketersediaan } \\
\text { Tempat } \\
\text { Pelayanan } \\
\text { Tidak Ada } \\
\text { Ada }\end{array}$ & $\begin{array}{c}34(82,9 \%) \\
137(42,3 \%)\end{array}$ & $\begin{array}{c}7(17,1 \%) \\
187(57,7 \%)\end{array}$ & 6,63 & $2,85-15,40$ & 0,00 \\
\hline 12 & $\begin{array}{l}\text { Pembiayaan } \\
\text { Tidak } \\
\text { Terjangkau } \\
\text { Terjangkau }\end{array}$ & $\begin{array}{c}38(38,8 \%) \\
133(49,8 \%)\end{array}$ & $\begin{array}{c}60(61,2 \%) \\
134(50,2 \%)\end{array}$ & 0,63 & $0,40-1,02$ & 0,06 \\
\hline
\end{tabular}




\begin{tabular}{|c|l|r|r|r|r|r|}
\hline 13 & $\begin{array}{l}\text { DukunganSua } \\
\text { mi } \\
\text { Tidak }\end{array}$ & $62(95,4 \%)$ & $3(4,6 \%)$ & 36,21 & $11,10-118,12$ & 0,00 \\
$\begin{array}{l}\text { Mendukung } \\
\text { Mendukung }\end{array}$ & $109(36,3 \%)$ & $191(63,7 \%)$ & & \\
\hline
\end{tabular}

Hasil analisis bivariat menunjukkan bahwa variabel bebas yang berhubungan dengan perilaku pemakaian kontrasepsi selama pandemi COVID-19 yaitu umur, paritas, penghasilan keluarga, persepsi manfaat, persepsi hambatan, ketersediaan tempat pelayanan, dan dukungan suami.

Tabel 4. Analisis Multivariat Determinan Faktor yang Mempengaruhi Perilaku Penggunaan Kontrasepsi Selama Pandemi COVID-19

\begin{tabular}{|r|l|r|r|r|}
\hline No & Variabel & OR & 95\% C.I. & Nilai $\boldsymbol{p}$ \\
\hline 1 & Persepsi manfaat tinggi & 4,4 & $1,08-10,42$ & 0,04 \\
\hline 2 & Persepsi hambatan rendah & 18,07 & $0,17-0,52$ & 0,00 \\
\hline 3 & Pembiayaan pelayanan & 10,1 & $0,18-0,67$ & 0,00 \\
\hline 4 & terjangkau & & & 0,00 \\
\hline
\end{tabular}


Berdasarkan analisis multivariat yang telah dilakukan dengan batas nilai $p$ yang dimasukkan dalam analisis multivariat yaitu $p<0,25$. Persepsi manfaat menghasilkan OR sebesar 4,4 (95\% CI=1,08-10,42) yang artinya bahwa responden yang memiliki persepsi manfaat tinggi akan manfaat pemakaian kontrasepsi akan memiliki peluang 4,4 kali lebih tinggi untuk menggunakan kontrasepsi.

Persepsi hambatan rendah menghasilkan OR sebesar 18,07 (95\% CI=0,17-0,52) yang artinya bahwa responden yang memiliki persepsi hambatan yang rendah akan memiliki peluang 18,07 kali lebih tinggi untuk menggunakan kontrasepsi.

Pembiayan pelayanan yang terjangkau menghasilkan OR sebesar 10,1 (95\% $\mathrm{CI}=0,18-0,67$ ) yang artinya bahwa responden yang menyatakan biaya pelayanan kontrasepsi terjangkau memiliki peluang 10,1 kali lebih tinggi untuk menggunakan kontrasepsi.

Variabel dukungan suami menghasilkan OR sebesar 27,37 (95\% CI=8,48-109,94) yang artinya bahwa responden yang menyatakan mendapatkan dukungan suami memiliki peluang 27,37 kali lebih tinggi untuk menggunakan alat kontrasepsi. Hasil penelitian ini didapatkan faktor yang paling dominan mempengaruhi perilaku dalam penggunaan kontrasepsi pada masa pandemi COVID 19 adalah dukungan suami.

Hasil penelitan ini didukung oleh penelitian lainnya yaitu Sabila dan Maisya Tahun 2016, menyatakan dari hasil penelitian kualitatif yang dilakukan tentang penggunaan kontrasepsi steril pada wanita didapatkan bahwa wanita yang menggunakan kontrasepsi sterilisasi menyatakan mendapat dukungan yang penuh dari suami. Adapun contoh dukungan yang diberikan suami terhadap istri yang melakukan sterilisasi antara lain: bersedia membiayai, mengantar ke pelayanan kesehatan, menemani sampai akhir dari tindakan, menandatangani persetujuan lewat informed counsent dan memberikan keputusan, [12].
Hasil penelitian ini juga didapatkan bahwa $63,7 \%$ suami mendukung dan menggunakan kontrasepsi. Dukungan suami yang baik akan memudahkan istri untuk menentukan alat kontrasepsi, banyak para wanita usia subur (WUS) yang takut menggunakan alat kontrasepsi disebabkan beberapa faktor diantaranya yaitu: takut untuk berat badan bertambah, perubahan postur tubuh atau bahkan mengalami perubahan integritas kulit. Dengan dukungan suami maka wanita usia subur akan mudah untuk menggunakan kontrasepsi [13]

Penelitian ini sejalan dengan penelitian Bella Novita tahun 2015 yang menyatakan bahwa, dukungan suami berpengaruh terhadap pengambilan keputusan istri untuk menggunakan alat kontrasepsi. Contoh dukungan suami terhadap istri antara lain berupa: dukungan emosional seperti berdiskusi dan berkomunikasi yang baik; memberikan dukungan penghargaan seperti memberikan persetujuan untuk menggunakan salah satu alat kontrasepsi yang tersedia; dukungan instrumental meliputi memberikan bantuan yang dibutuhkan seperti suami bersedia untuk membiayai, bersedia mengantar istri ke fasilitas pelayanan kesehatan untuk mendapatkan pelayanan KB[14]. Menurut Kundre \& Rina tahun 2018, suami-istri secara bersama-sama dalam mendiskusikan dan memilih metode kontrasepsi yang sesuai, membiayai pengeluaran pelayanan kontrasepsi dan bersama-sama memperhatikan efek samping dari pemakaian kontrasepsi yang dipilih [13].

Dukungan suami merupakan pedoman penting bagi istri untuk menggunakan alat kontrasepsi. Peran serta suami dalam dalam mendukung pengambilan keputusan, juga sangat berpengaruh dalam memberikan informasi bagi istri. Dukungan sebagai edukator yang dapat diberikan oleh suami kepada istri antara lain suami ikut saat melakukan konsultasi ke tenaga kesehatan dalam hal pemilihan alat kontrasepsi, mengingatkan kepada istri untuk jadwal minum obat atau jadwal kunjungan ulang dan sebagainya dapat meningkatkan motivasi istri 
menggunakan alat kontrasepsi[15].

Hasil penelitian ini juga didapatkan sebesar 36,3\% suami mendukung, tetapi ibu tidak menggunakan kontrasepsi, dengan adanya pertimbangan lainnya yang mempengaruhi perilaku pemakaian kontrasepsi. Hasil analisis bivariat didapatkan bahwa variabel persepsi juga mempengaruhi perilaku dalam penggunaan kontrasepsi. Responden yang menilai dirinya tidak berisiko tinggi untuk hamil, kemungkinan tidak menggunakan kontrasepsi yang efektif [16]. Dalam penelitian ini responden yang memiliki persepsi akan dirinya berisiko tinggi untuk bila hamil akan tetap menggunakan alat kontrasepsi walaupun saat ini masih dalam keadaan pandemi COVID-19.

Pengalaman responden selama menggunakan alat kontrasepsi dan informasi yang diperoleh pada fasilitas pelayanan kesehatan baik dari puskesmas, dokter praktek mandiri, praktek bidan dan rumah sakit, media cetak dan elektronik serta informasi dari akseptor lain yang telah menggunakan alat kontrasepsi tertentu akan menimbulkan suatu persepsi tersendiri. Adapun hal yang membuat seseorang merasakan tertarik kembali ke sesuatu hal yang dianggap baik dan aman bisa disebabkan oleh karena pengalaman yang baik sebelumnya. Saat pendemi COVID-19 sekarang ini banyak menimbulkan berbagai persepsi ibu mengenai pemenuhan pelayanan kontrasepsi karena dari Pemerintah menghimbau untuk tetap drumah saja. Disisi lain akseptor KB memerlukan pelayanan kontrasepsi sesuai dengan jadwal ke fasilitas pelayanan kesehatan.

Pemerintah dengan segala upaya promotif dan preventifnya menghimbau kepada seluruh pasangan usia subur sebaiknya merencanakan dengan baik dan atau menunda kehamilan sampai kondisi pandemi COVID-19 berakhir dengan memperhatikan kondisi layak hamil, kemudahan dalam mengakses pelayanan kesehatan yang berkualitas dan perencanaan kehamilan dilakukan dengan memastikan apakah sudah layak untuk hamil [3].

Pelayanan kontrasepsi saat ini dalam masa situasi pandemi COVID-19 yang dihimbau oleh Pemerintah adalah sebagai berikut: Menunda kehamilan sampai kondisi pandemi berakhir; Akseptor dihimbau untuk tidak datang ke fasilitas kesehatan, kecuali yang memiliki keluhan, dan dengan syarat telah membuat perjanjian terlebih dahulu dengan petugas; Bagi akseptor IUD/Implan yang telah habis masa pakai alat kontrasepsi, jika memungkinkan untuk menggunakan kondom; Bagi akseptor KB Suntik dihimbau untuk datang ke fasilitas kesehatan sesuai jadwal dengan membuat perjanjian sebelumnya melalui telepon atau pesan elektronik; Bagi akseptor KB Pil diharapkan dapat menghubungi kader atau petugas PLKB untuk mendapatkan Pil KB; Ibu yang telah melahirkan sebaiknya langsung menggunakan KB pasca salin (KBPP), materi komunikasi, edukasi dan konseling dapat diberikan secara daring atau online[3].

Perilaku penggunaan alat kontraspesi selama pandemi COVID-19 di Kecamatan Kuta Utara didapatkan bahwa setengahnya yaitu 53,2\% responden saat ini sedang menggunakan alat kontrasepsi dan hampir setengahnya yaitu $46,8 \%$ responden tidak sedang menggunakan alat kontrasepsi. Hasil tersebut menunjukkan hampir seimbang antara wanita yang sedang menggunakan kontrasepsi dan wanita yang tidak sedang menggunakan kontrasepsi. Sejak ditetapkannya COVI-19 sebagai bencana Nasional berdasarkan Keputusan Presiden Nomor 12 tahun 2020, memberikan efek yang sangat besar untuk seluruh aspek kehidupan salah satunya adalah dalam pelayanan kesehatan masyarakat termasuk pelayanan kontrasepsi.

Diberlakukannya kebijakan Pembatasan Sosial Berskala Besar (PSBB) dapat mengakibatkan terhambatnya distribusi dan akses untuk mendapatkan pelayanan kontrasepsi sehingga dapat menyebabkan akseptor drop out $\mathrm{KB}$ atau 
putus kesertaan ber-KB. Hal ini akan sangat berpengaruh terhadap terjadinya kehamilan yang tidak diinginkan (KTD), oleh karena penurunan jumlah pemakaian kontrasepsi dari masing-masing jenis alat kontrasepsi. Keadaan ini diindikasikan oleh karena pasangan usia subur (PUS) yang memerlukan pelayanan kontrasepsi tetapi tidak mampu mengakses layanan dan menunda ke fasilitas pelayanan kesehatan selama pandemi COVID-19 yang disebabkan oleh kekhawatiran PUS yang akan tertular COVID-19 [3].

Hasil penelitian ini didapatkan bahwa faktor dominan yang mempengaruhi penggunaan kontrasepsi adalah dukungan suami, dimana diharapkan suami dapat tetap mendukung ibu untuk mendapatkan pelayanan kontrasepsi sehingga tetap terpenuhi kebutuhan untuk berKB.

\section{KESIMPULAN}

Dapat disimpulkan dari hasil penelitian yang dilakukan bahwa, dukungan suami adalah faktor dominan yang mempengaruhi penggunaan kontrasepsi dimasa pendemi COVID-19

\section{UCAPAN TERIMAKASIH}

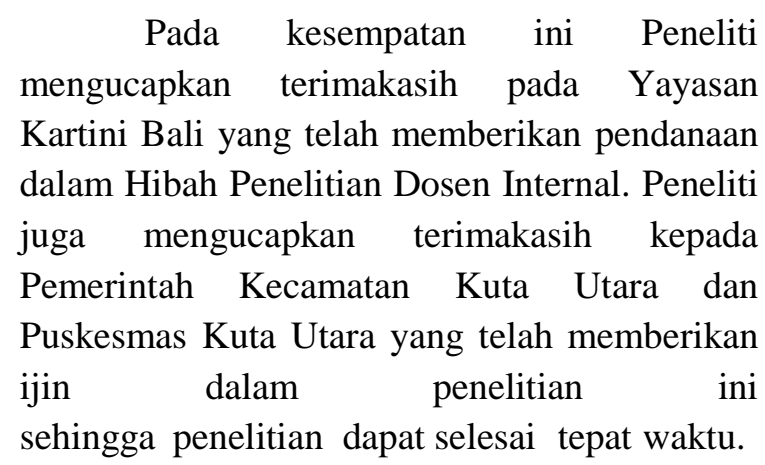

\section{DAFTAR PUSTAKA}

[1] Kemenkes RI, "Pedoman Manajemen Pelayanan KB," 2018.

[2] Kementerian Kesehatan RI, "Pedoman dan Pencegahan Coronavirus (COVID19)," pp. 1-214, 2020, doi: 10.33654/math.v4i0.299.

[3] B. Kemenkes RI, "Panduan Pelayanan
Keluarga Berencana dan Kesehatan Reproduksi Dalam Situasi Pandemi COVID-19," kemenkes RI, p. 5, 2020.

[4] BNBP RI, "Presiden Tetapkan COVID19 Sebagai Bencana Nasional," Jurnal Berkala Kesehatan, 2020. .

[5] J. Aly, K. O. Haeger, A. Y. Christy, and A. M. Johnson, "Contraception access during the COVID-19 pandemic," Contracept. Reprod. Med., vol. 5, no. 1, pp. 1-9, 2020, doi: 10.1186/s40834-02000114-9.

[6] C. Purdy, "How will COVID-19 affect global access to contraceptives and what can we do about it?," Devex, 2020.

[7] UNFPA, "Sexual and Reproductive Health and Rights: Modern Contraceptives and Other Medical Supply Needs, Including for COVID-19 Prevention, Protection and Response," 2020, [Online]. Available:

https://www.unfpa.org/resources/sexualand-reproductive-health-and-rightsmodern-contraceptives-and-othermedical-supply.

[8] Kementrian Kesehatan, "Pedoman COVID REV-4," Pedoman Pencegah. dan Pengendali. Coronavirus Dis., vol. 1, no. Revisi ke-4, pp. 1-125, 2020.

[9] E. W. Zhou, "101 Tips Berbasis Sains," Buku Pandu. Pencegah. Coronavirus 101 Tips Berbas. Sains Yang Dapat Menyelamatkan Hidup Anda, p. 120, 2020, [Online]. Available:

https://fin.co.id/wpcontent/uploads/2020/03/BukuPanduan-Pencegahan-Coronavirus-101Tips-Berbasis-Sains.pdf.

[10] Stephan dan Ariyani, "Gambaran perilaku pemakaian kontrasepsi pasca persalinan pada wanita usia subur di desa gelgel, Klungkung-Bali Published," Intisari Sains Medis, vol. 8, no. 2, pp. 144-146, 2017, doi: 10.1556/ism.v8i2.130.

[11] S. Notoadmodjo, "Promosi Kesehatan \& Prilaku Kesehatan," Jakarta EGC, 2012.

[12] M. Sabilla and I. Maisya, "Gambaran Perilaku Wanita Dalam Penggunaan Kontrasepsi Strerilisasi Wanita Di Pamulang, Kota Tangerang Selatan," Indones. J. Reprod. Heal., vol. 7, no. 3, pp. 185-197, 2017, doi: 10.22435/kespro.v7i3.6662.185-197.

[13] R. Kundre, "Hubungan Dukungan Suami Dengan Pemilihan Jenis Kontrasepsi Intra Uterine Device Pada Wanita Usia Subur Di Puskesmas 
Makalehi Kecamatan Siau Barat," J. Keperawatan, vol. 6, no. 2, pp. 1-7, 2018.

[14] Bela Novita Amaris Susanto, "Hubungan dukungan suami terhadap istri dalam dengan keputusan penggunaan alat kontrasepsi.," pp. 1-14, 2016.

[15] L. Choiriyah, N. K. A. Armini, and S. Hadisuyatmana, "Dukungan Suami dalam Pemilihan Metode Kontrasepsi Jangka Panjang (MKJP) pada Pasangan Usia Subur (PUS).," Indones. J. Community Heal. Nurs., 2020, doi: 10.20473/ijchn.v5i2.18481.

[16] T. Alami, D. Diniyati, and I. Netty, "Hubungan Persepsi Akseptor Kb Dengan Pemilihan Mkjp Di Kelurahan Tahtul Yaman Kota Jambi Tahun 2017," J. Ilm. PANNMED (Pharmacist, Anal. Nurse, Nutr. Midwivery, Environ. Dent., vol. 14, no. 2, pp. 9-16, 2019, doi: 10.36911/pannmed.v14i2.539. 